\title{
Åndens hermeneutik
}

\section{En læsning af I al sin Glands nu straaler Solen}

\section{Af Jakob Ulrik Hansen}

Det er bemærkelsesværdigt, hvordan Grundtvig i sin salmedigtning kan forene begivenheder fra helt forskellige historiske og litterære kontekster. Tilsyneladende bevæger han sig ubesværet mellem beskrivelser af årstidens natur, det bibelske univers, sagnberetninger og historiske begivenheder uden særlige spekulationer om tid. Ved en gennemgang af salmen I al sin Glands nu straaler Solen diskuterer nærværende artikel, hvad der er med til at muliggøre denne særlige form for poetisk hermeneutik.

Når man slår op i Salmehåndbogen, hedder det om Grundtvigs pinsesalme I al sin Glands nu straaler Solen (GSV VI, 268), at salmen ikke er naturlyrik, men den virkeliggjorte pinse i menighedens lovsang. I forlængelse af det citeres Magnus Stevns: "Det er aldeles ikke dansk Sommer, der er Tale om, men Aandens Sommer: Det er ikke den astronomiske Sol, men 'Livslyset over Naadestolen', der straaler i al sin Glans" (Kjærgaard 2003, 299). Formuleringen er forståelig. Det er naturligvis andet og mere end den danske sommer, der er tale om. Men spørgsmålet er, om de to benægtelser giver mening. Åndens sommer udelukker vel ikke allusionerne til den danske sommer, og nådestolens livslys er næppe en modsætning til den astronomiske sol. Problemet er, hvordan man skal forstå salmens naturlyrik. Kan man reducere tekstens billeder til håndfast teologisk dogmatik uden derved at gøre vold på tekstens anliggende?

Artiklen former sig som en fortolkende gennemgang af salmens syv strofer. Tekstgrundlaget for analysen er den kendte version af salmen, som efter en række redigeringer af et tidligere forlæg, der sandsynlig stammer fra $1842,{ }^{1}$ finder sin endelige form i 5. oplag af Fest-Psalmer i $1853 .{ }^{2}$ Undervejs vil tidligere versioner af salmen lejlighedsvis blive inddraget som hjælp i fortolkningen.

I artiklen "Opblomstrer nu Guds Kirkevange" påpeger Jette Holm (Holm 1999) ved at sammenholde salmeteksten med Grundtvigs prædikener fra 1842 sandsynligheden for, at digtningen af salmen påbegyndes i 1842 og ikke 1843 som hidtil antaget. Salmen "Opblomstrer nu Guds Kirkevange" findes i tre håndskrifter, hvoraf kun den seneste kom til at indgå i samlingen PsalmeBlade til Kirke-Bod.

2 Fest-Psalmer, 5. opl. 1853 nr. 739. 


\section{Strofe 1: Pindselilje-Tid}

I al sin Glands nu straaler Solen,

Livs-Lyset over Naadestolen,

$\mathrm{Nu}$ kom vor Pindselilje-Tid,

$\mathrm{Nu}$ har vi Sommer skiær og blid,

$\mathrm{Nu}$ spaaer os meer end Englerøst

I Jesu Navn en gylden Høst!

Allerede i salmens første linje markeres den insisterende nutid, som fortsætter resten af strofen. Nuet gentages som anaforisk indledning til linje 3, 4 og 5. Der er formentlig tale om det stærke sollys midt på dagen, dér hvor solen står højest. I en tidligere version hedder det samme sted: "I Middags-Glands" (GSV VI, 268). Samtidig kunne ordet "Glands" være en allusion til begivenhedens guddommelige karakter. Glans $(\delta \circ \xi \alpha)$ anvendes i Bibelen tit om et særligt lys, der adskiller sig fra solens lys, og forbindes med lejligheder, hvor Gud er til stede og forbindelsen mellem himmel og jord er åben (Es 58,8;60,1 og 60,19).

Denne forestilling om to slags lys findes også i Nyaars-Morgen fra 1824, hvor der omtales en sommermorgen, der ligefrem er oplyst af to sole: En sol, som lyser over støvhytter og alt det, der har dødningekår, og en sol (Kristus), der stråler fra det høje "i Kraft og med Glands" (US IV, 251). ${ }^{3}$ De to sole supplerer hinanden. ${ }^{4}$

Tolkningen underbygges af anden linje om "Livs-Lyset over Naadestolen", hvormed der etableres en verden i to planer, som bliver konstituerende for salmens videre forløb. Nådestolen er det gulddække, som var placeret over pagtens ark (2 Mos 25,17-22 og 4 Mos 7,89). Udsmykket med to keruber befandt det sig i tabernaklet og senere i templets allerhelligste. Dækkenet er traditionelt blevet set som præfigurering af Kristus, for eksempel i Luthers oversættelse af Romerbrevet, hvor Kristus er blevet et sonedokke ved troen. ${ }^{5}$ Nådestolen er således også udtryk for den nye pagt ved korset på Golgata, hvorved livslyset over nådestolen kommer til at alludere til det evige liv. Den appositionelle sammenhæng mellem det lys, som

\section{Jf. Auken 2005, $364 \mathrm{f}$.}

4 Ifølge Toldberg må forståelsen af lyset som symbol søges forstået i den nikæiske trosbekendelse, hvor $\varphi \omega ́ \varsigma \varepsilon \kappa ~ \varphi \omega \tau o ́ \varsigma$ (lys af lys) er et navn for Kristus. Toldberg påpeger, at de glødende tunger i pinseunderet er et udtryk for denne side af Guds væsen (Toldberg 1950, 119). Spørgsmålet er, om han ikke derved overser billedets dobbelthed. Et problem, der kun forstærkes af, at Grundtvigs gennemgående uvilje over for den nikænske trosbekendelse gør det tvivlsomt, om han ville anvende en sådan allusion.

5 Die Bibel, Martin Luther (Rom 3,25). 
stråler nu, og livslyset forlener hermed den konkrete natur eller virkelighed med åndelig dybde.

De to indledende linjer er et brud med første version af salmen fra 1842, der ellers bortset fra disse linjer med forholdsvis få ændringer er identisk med de seks første strofer i den senere udgave. I den tidlige version lyder linjerne: "Opblomstrer nu, Guds Kirkevange! / Gienlyder trindt af Lærkesange!" (GSV III, 514). Det er vanskeligt at vide, hvorfor den ændring er kommet til. Man kunne dog i tråd med ovenstående gætte på, at Grundtvig med redigeringen har villet betone pinsens sammenhæng med forsoningen og desuden forberede den sammensmeltning af naturen og Guds rige, der foregår ved åndens komme i de senere strofer. Hvor den første salmes indledende linjer blot udtrykker opfordringen til Guds kirkes vange eller menigheder om at vokse og blomstre, har den senere salme en mere universel beskrivelse af pinsens under gennem lys og glans i verden. Her gælder salmens udsagn hele den skabte natur.

I v. 3 angives tiden nærmere: "Nu kom vor Pindselilje-Tid". Hos Grundtvig møder man flere steder liljer og udfoldede beskrivelser af dem. I denne salme hentydes mere specifikt til tidspunktet. I prædikenen til pinsedag 1842 - i forbindelse med hvilken den første version af salmen kunne være forfattet - hedder det:

det vare længe eller kort før Pindse-Lilien kan aabenbar udspringe og udfolde sig i den ny Menighed som i den Gamle, saa lad os holde fast ved hvad vi har: Oplysningen om, at det Sidste skal være som det Første, saa den Hellig-Aand aabenbarer sig baade først og sidst med Tunger som af Ild hos Ordets Tjenere (GPV III, 234).

Både i prædikenen og i salmen symboliserer pinseliljen tidspunktet for åndens komme. Men årstidens tegn har mere at fortælle. I julesalmen Velkommen igien, Guds Engle smaa (GSV I, 405) spår engle trods klingrende frost om forår og sommer, men i pinsen er englenes udsagn realiserede i naturen. Måske derfor er der tale om mere end englerøst. Det siges dog ikke direkte, hvad "meer" refererer til. Men det må underforstås, at det er pinsetiden og sommernaturen - måske det endnu ikke gulnede korn - der giver løfte om en gylden høst.

\section{Strofe 2: Natten}

I Sommer-Nattens korte Svale

Slaaer høit Fredskovens Nattergale,

Saa alt hvad Herren kalder sit

Maa slumre sødt og vaagne blidt,

Maa drømme sødt om Paradis,

Og vaagne til Vorherres Pris. 
De danske sommernætter er korte og svale, og dermed ikke modpol til dagens lys og varme. Det er heller ikke nattens stilhed, der beskrives, men den højlydte nattergalesang. Samtidig synes nattergalenes sang mere at være vuggevise end et signal til opvågnen, hvorfor Stevns sammenligner Fredskovens nattergale med englene i Grundtvigs julesalmer (Stevns 1950, 50 f.). I strofen bliver sommernatten således en afventende tilstand midt i skovens fredsommelighed. ${ }^{6}$

Med udtrykket fredsskoven skal man ikke glemme referencen til den konkrete historiske virkelighed. I løbet af 1700-tallet blev danske skove faretruende reduceret. Kun fire procent af skovarealet var tilbage (Vaupell 1865, 6 f.). Svenskerkrigene havde gjort et stort indhug i skovene, da de belejrende svenskere havde fældet meget. Ligeledes var skovene langt hen ukontrolleret blevet brugt til dyreindhegninger, indsamling af byggemateriale og brænde. Derfor blev der i 1805 gennemført den såkaldte Fredskovordning, som pålagde skovejere at 'indfrede' deres skove ved at bygge hegn om dem, samtidig med at man forbød al græsning i skovene. Det bevirkede, at skovarealerne voksede, og at skovene de næste årtier forståeligt nok også blev et fredeligt sted at opholde sig (Vaupell 1865, $27 \mathrm{f}$.). ${ }^{\text {. }}$

Billedet af fredskoven lægger op til de efterfølgende billeder af at sove og drømme sødt. Også i Velkommen igien, Guds Engle smaa drømmes sødt - ikke om paradis - men om "Barnets Hjem" (GSV I, 405) med en henvisning til Jesu fødested (Luk 2,7). Her i salmen handler drømmen om paradis, hvorfra verden udgik, og hvormod de menneskelige håb retter sig.

Drømmen om paradis efterfølges i strofens sidste linje af udsagnet om en opvågnen til Vorherres pris. Også andre steder hos Grundtvig kan lovprisningen skabe en paradisisk tilstand og hensætte den lovsyngende til Paradis. ${ }^{8}$ I salmen Jeg troer det, min Gienløser! lyder

6 I Rom 13,12 hedder det, at natten er fremrykket og dagen er nær. Dette bliver endnu stærkere udtrykt i pinsesalmen "Den signede Dag med Fryd vi seer" (GSV III, 161) fra 1826, hvor det siges "At Natten hun er nu omme!"

7 I en prædiken til Store Bededag 1842, samme år som pinsesalmens tilblivelse, beskriver Grundtvig naturens fredelige opvågnen: "Ja m. V. har vi nogensinde en Sommer-Morgen været Vidne til Solens Opgang og ret i Mag nydt den Fornøielse, det er at høre alt i Dæmringen alle Smaafuglene synge sig vaagne, og see hvordan den ene Skygge-Hær efter den anden ligesom flygter for Daglyset" (GPV III, 197), jf. Holm, 1999.

8 Også i andre salmer hos Grundtvig, hvor ordet 'Pris' indgår, er det lovsang, der er tale om. I salmer som "Vor Herres Jesu Mindefest" (GSV IV, 222-223), "Giv mig, Gud en Psalme-Tunge" (GSV I, 152-154), "Var I ikke Galilæer!" (GSV II, 264-266) og mange andre salmer betyder 'prise' og 'Priis' at lovsynge og lovsang til Gud. 
det: "At til din Guddoms Priis / Der dybt fra Hjerte-Grunden / Mig springer op i Munden / Et lille Paradis!" (GSV IV, 11). Drømmen om Paradis og lovprisningen af Herren forholder sig således hos Grundtvig mere til hinanden end blot at rime. De to ting hører tæt sammen, som det også vil fremgå af analysen af strofe 5 .

\section{Strofe 3: Paradis på ny}

Det aander himmelsk over Støvet,

Det vifter hjemlig giennem Løvet,

Det lufter liflig under Sky

Fra Paradis, opladt paany,

Og yndig risler ved vor Fod

I Engen Bæk af Livets Flod!

Ligesom $\mathrm{i}$ de to forrige strofer er billedsproget $\mathrm{i}$ strofe 3 hentet $\mathrm{i}$ naturen. "Det aander", "Det vifter" og "Det lufter". Med ordet "aander" og paralleliteten mellem de tre fænomener antydes her for første gang den direkte forbindelse mellem naturen og åndens komme. Men der synes også at blive alluderet til skabelsesberetningen på en måde, der minder om Grundtvig velkendte beskrivelse af mennesket som et guddommeligt eksperiment af støv og ånd (US V, 408). Det stemmer med, at strofen beskriver genåbningen af Paradis. Man kan måske sige det sådan, at salmen antyder, at det oprindelige eksperiment efter denne genåbning kan gentages fuldt ud.

Der findes en del forskellige tidligere variationer over anden linje. I den ældste af håndskrifterne hedder det: "Det suser liflig giennem Løvet". Det bliver i næste version rettet til "Det vifter venlig giennem Løvet", hvorefter Grundtvig har forsøgt sig med "kiærlig", "yndig", "sagte", "blidt", "lønlig", for endelig i Psalme-Blade til Kirke-Bod at ende på "hjemlig", som også fastholdes i salmen fra 1853. Beskrivelsen af åndens bevægelse gennem løvet er således blevet til ud fra mange overvejelser og afprøvede muligheder. Men hvad ligger bag Grundtvigs endelig valg, der tyder på, at han har prioriteret indhold over fonetisk vellyd? Ordet hjemlighed har selvfølgelig at gøre med det, som mennesket ikke er fremmed over for, og betyder, at mennesket føler sig fortrolig med vindens susen i trætoppene. Men forklaringen knytter sig formentlig endvidere til forbindelsen med det genåbnede paradis i linje fire. Når vinden er hjemlig, skyldes det, at den kommer derfra, hvor mennesket hørte hjemme. Ingen eller intet er derved tilbage i Paradis, men der er atter åbnet en forbindelse mellem Paradis og verden udenfor.

Noget lignende gør sig gældende i vers 3,5 og 6 . I alle tidligere versioner af vers 3 hedder det, at, "Det dufter liflig under Sky", men 
nu altså "lufter". Den endelige version betoner hermed tanken om, at ånden bevæger sig ved at blæse, vifte og lufte. Det er et gennemgående træk hos Grundtvig, at ånd beskrives som vind, det vil sige som et åndepust fra det høje, der blæser igennem verden (Wigh-Poulsen 1991, 68 f.).

Men også i form af vand udtrykkes forbindelsen tilbage. I Paradis, var livets flod den kilde, som vandede Edens have. Uden for paradiset delte floden sig til flere floder, der løb ud i verden (1 Mos 2,10 f.). Det er en mulighed, at der samtidig alluderes til "livets vand", der udspringer som flod fra Guds og Lammets trone i Johannes' Åbenbaring (Åb 22,1). Hvad enten denne allusion er medtænkt eller ej, bestyrker billedet en lokal rislende flod med livets vand tanken om en genåbning af paradis, der har betydning i nutidens sommerlandskab.

\section{Strofe 4: Ånden i verden}

Det volder Alt den Aand, som daler,

Det virker Alt den Aand, som taler

Ei af sig selv, men os til Trøst,

Af Kiærlighed med Sandheds Røst,

I Ordets Navn, som her blev Kiød,

Og foer til Himmels hvid og rød!

Efter tre strofer, som kun antyder åndens tilstedeværelse, tales der $\mathrm{i}$ strofe 4 for første og eneste gang direkte om ånden. Den bliver hermed salmens midte, ikke blot som den fjerde strofe ud af syv, men også som forståelsesmæssigt centrum. Strofen kan betragtes som en opsummering af det, som de tre forrige udtrykker: Ånden volder og virker alt det, de andre peger frem imod. ${ }^{9}$

Strofens to første linjer anviser en særlig rækkefølge ved åndens komme: Ånden må først dale for at kunne tale i verden (ApG 2,1-4). Ånden må være $\mathrm{i}$ verden for at kunne tale, men den taler ikke af sig selv, og som menneskets trøster er den ikke selvstændig virkende, men en del af den guddommelige treenighed. Helligånden kan ikke adskilles fra Gud-Faders kærlighed og sandhedens røst i Kristus, Ordet. Guds ord lod sig inkarnere i verden, men er nu faret til himmels. Nu er det ånden, der virker og taler i verden, for nu er det åndens tid.

Den væsentligste pointe er dog, at det er ånden, der virker “Alt”. Uden ånden ville verden ikke være i forbindelse med Paradis på ny, $\mathrm{i}$ hvert fald ikke sådan, at Paradis, pinsebegivenhed og nutid kunne være

9 I salmen fra 1842 indledes de to første linjer i denne strofe med udsagnet "Det virker". I de tidligere håndskrifter hedder det samme sted "Det volder". I salmen fra 1853 gør ånden begge dele. Måske fordi ingen af delene kan undværes. Ånden er både årsag og i sig selv virkende. 
til stede samtidigt. Gennem ånden forenes himmel og jord, og Paradiset kan være hjemligt. Det er ånden, der muliggør salmens særlige hermeneutik.

Der har i forskningen været delte meninger om Ordet, som fór til himmels hvid og rød. Disse farver kunne henvise til renhedens og Helligåndens farver. Verselinjen kunne også lede tankerne i retning af Højsangen, hvor der står "Min elskede er hvid og rød" (Højs 5,10). Mest naturligt er det måske at lade rød og hvid betyde den sunde krops farver (Tårup 1939, 30). Kristus bærer således et levende legemes naturlige farver ved himmelfarten.

Også en Dannebrogsassociation har været nævnt som nærliggende (Kjærgaard 2003, 299). I givet fald skulle der associeres til noget med inkarnationens betydning i den lokale danske sammenhæng. Tolkningen er vanskelig. Sagnet om Dannebrog beretter om, hvordan flaget dalede ned og bragte sejrstro. I salmen går bevægelsen nærmest modsat, eller i hvert fald både nedad og opad: Nok er det ånden, der daler ned og taler i verden, men det er Kristus, som for til himmels "hvid og rød". Det er svært at få til at gå helt op.

\section{Strofe 5: Opvågnen}

Opvaagner alle dybe Toner

Til Pris for Menneskets Forsoner!

Forsamles alle Tungemaal,

I Takkesangens Offerskaal!

Istemmer over Herrens Bord

$\mathrm{Nu}$ Menighedens fulde Kor!

Hvor str. 2 beretter om nat med slummer og drømme, opfordrer bydemåden her til opvågnen med lovsang. Således synes denne strofe at forklare betydningen af udsagnet om at vågne til Vorherres pris i str. 2. Menneskets forsoner er nu faret til himmels og sidder på nådestolen, og i pinsen kan menigheden stemme i. De "dybe Toner" kan være den nærværende menigheds sang, men kan ligeså vel være uudgrundelige stemmer fra fortiden (jf. $O D S$ ). Med en slet skjult reference til pinsebegivenheden og den babelske spredning af sprogene opfordres der i forlængelse af det til, at alle tungemål samler sig i takkesangens offerskål. Det har også været foreslået, at offerskålen alluderer til kalken på alterbordet, "Herrens Bord". Inspirationen til at knytte disse sammen skulle så være hentet i østkirkens nadverteologi. I østkirken anskues nadveren ikke blot som Kristi død og opstandelses nærvær, men også som en gentagen fornyelse af pinsen. Pinsen er den begivenhed, hvor Helligånden i form af flammende ild satte sig på apostlene, og dette skabte i østkirken forestillingen om tilstedeværelsen af ild i 
nadveren. Det vil sige, at ånden daler ned og fylder kalken med ild (Allchin 1997, 149). Dette kunne understøttes af de to ældste håndskrifter af salmen, hvor ild-motivet i nadveren er endnu stærkere udtrykt. Her lyder det: "Hensmelter alle Tungemaal / I Kirke-Sangens Offerskaal, / Ved Aandens Ild, paa Herrens Bord / Til Kiærlighedens fulde Chor!".

Til sidst opfordres "Menighedens fulde Kor" til at stemme i. Ligesom i str. 1 understreger nuet tidspunktet for intentionen med denne handling. Det bevirker, at temperaturen i salmen stiger.

\title{
Strofe 6: Hensmeltning
}

\author{
I Jesu Navn da Tungen gløder, \\ Hos Hedninger saavelsom Jøder; \\ I Jesu-Navnets Offerskaal \\ Hensmelter alle Modersmaal; \\ I Jesu Navn udbryder da \\ Det evige Halleluja!
}

Som det fremgik af strofe 4, taler ånden ikke af sig selv. Tilsvarende her, hvor det tre gange bliver påpeget, at det er i Jesu navn, de sproglige virkninger af pinsebegivenheden finder sted. Ordet "da" udtrykker i strofens sammenhæng, hvad der følger efter det skete.

Grundtvig omdanner billedet fra Apostlenes Gerninger, hvor tunger som af ild sætter sig på apostlene (ApG 2,3), og i salmen er det tungen, der gløder ved Helligåndens ild. Billedsproget synes hentet fra smedehåndværket, hvor metal opvarmes, gløder og smeltes. Når alle sprog gløder og bliver flydende, opretholdes grænserne ikke længere i mellem dem, og sådan bliver de forenet. Samtidig peges der også denne gang i retning af gudstjenestens nadver, hvis Jesus-navnets offerskål forstås som kalken, og alle forsamlede ved gudstjenestens alterbord. Her forenes alle i ét fælles sprog.

Det sker i ordet: Halleluja. Det hebræiske ord, lovsyng Jahve, beskrives som en lyd fra talrige engleskarer ( $\AA$ b 19,1 f.), og i den kristne tradition forbliver ordet uoversat og fremstår som et fremmedord i andre jordiske sprog. I Grundtvigs salmer knyttes ordet halleluja som i Bibelen ofte til begivenheder, hvor engle er til stede og bringer nye budskaber. ${ }^{10}$ I salmen Sov sødt Barnlille proklameres det, at alle,

10 Eksempelvis "Et lidet Barn saa lysteligt" (GSV III, 492), "Stat op i Gry, min Gud! stat op!" (GSV I, 430-432), "Herren af Søvne opvaagned, opsprang" (GSV I, 430-432). 
der døbtes i Jesu navn, en gang skal "Istemme saa lydt / Halleluja nyt / At Englene tie og smile" (GSV IV, 48). ${ }^{11}$

Det synes netop at være sådan en begivenhed, der beskrives i sidste linje af sjette strofe: Samtidig er det også foreningen af alle tider. Alle tider smelter sammen, idet der ikke blot er tale om et halleluja, men "det evige halleluja". Med andre ord: I strofen forenes alle sprog og alle tider.

\title{
Strofe 7: Herlighed
}

\author{
Vor Gud og Fader uden Lige! \\ Da blomstrer Rosen i dit Rige, \\ Som Sole vi gaae op og ned \\ I din Eenbaarnes Herlighed; \\ Thi Du for Hjertet, vi gav Dig, \\ Gav os med ham dit Himmerig!
}

I strofe 7, som først bliver tilføjet i 1853, trædes der helt ind i evighedens verden, dog uden at forbindelsen med den dennesidige ophører. De to finitte verber i strofens fire første linjer er præsens indikativ. Ordet "da" angiver som tidligere i salmen pinsebegivenhedens følge. Med åndens nærvær i pinsen følger Guds rige. Når "vi" netop her går op og ned som sole $\mathrm{i}$ den enbårnes herlighed, må det være et billede på, at Gudsriget, som kommer med pinsen, skænker menneskelivet fra fødsel til død et perspektiv. ${ }^{12}$

Salmen afsluttes i datid. De to sidste linjer retter sig imod Guds og menighedens forhold: Gud har med Kristus givet sit himmerig for hjertets tro. Det virker alt den ånd.

\section{Åndens hermeneutik}

Om salmen skriver Carl Koch allerede i 1925 i karakteristisk modsætning til Stevns: "Dette er ikke en haandfast Natur-Allegori, der kræver Udlæggelse af alle enkelte Træk. Men med næsten legende Ynde er Naturbilleder og den aandelige Virkelighed slynget sammen til en

11 Et lignende udsagn findes i salmen "Lyksaligt det Folk, som har Øre for Klang". Her forundres englene over, hvor himmelsk det kan lyde fra det jordiske. "Lyksaligt det Folk, som har Øre for Klang / Herovenfra! / Det nynner alt her paa den evige Sang: / Halleluja. / Saa alle Guds Engle forundres paa, / Hvor himmelsk de jordiske Klokker slaae, / Naar Aanden med Støvhjertets Tunger / Dets dybeste Længsel udsjunger!" (GSV IV, 351).

12 I sidste strofe af "Morgenstund" (GSV IV, 338) beskrives menneskelivet på en lignende måde. 
bøjelig Snor, der ikke strammer og spærrer, men leder ind i Egne, hvor man saa selv kan vandre videre og finde og genkende egne Oplevelser - eller maaske komme til at føle Savnet deraf og længes derefter” (Koch 1925, 76-77).

I tilslutning til dette udsagn må der videre spørges om, hvad det er, der muliggør forholdet mellem den legende ynde og åndelig virkelighed i salmen. Det er et spørgsmål, som selvfølgelig ikke udtømmende lader sig besvare, men det hænger utvivlsomt sammen med åndsbegrebet. Grundtvigs hermeneutik, hvor de mange begivenheder, tider og modsætninger danner enhed, forudsætter et særligt åndsbegreb. Dermed mener jeg ikke bare, at når Grundtvig digter, er det ånden, der fører den pen, hvormed der skrives. ${ }^{13}$ Min pointe er, at det bliver vanskeligt at forstå Grundtvigs særlige poetiske hermeneutik uden sammenhæng med hans forestillinger om ånd. Betingelsen for så ubesværet at kunne inddigte pinsebegivenheden i nutiden kan vanskeligt stamme fra andet end en overbevisning om, at den samme kraft kan være til stede på forskellige tider.

Når jeg netop har fundet det centralt at betragte en af Grundtvigs væsentligste og kendte pinsesalmer, er det sket ud fra en fornemmelse af, at Grundtvigs tanker om pinse og ånd på en særlig måde kan vise os denne særlige hermeneutik, der også forekommer mig at være til stede i mange andre af hans salmer.

\section{Forkortelser}

GPV I-IV: Jette Holm m.fl. i samarbejde med Chr. Thodberg (udg.) (2003), Grundtvig Prcedikener $i$ Vartov, 1839-42, I-IV, inkl. kommentarbind (IV), København.

GSV I-VI: Th. Balslev m.fl. (udg.) (1944-64), Grundtvigs Sang-Vark, I-VI, København.

US I-X: Holger Begtrup (udg.) (1904-09), Nik. Fred. Sev. Grundtvigs Udvalgte Skrifter, I-X, København.

\section{Litteraturliste}

\section{Verker af Grundtvig}

Grundtvig, N. F. S. (1853), Fest-Psalmer, 5. opl., København.

13 Forestillingen om et særligt forhold mellem ånden og digteres fjerpen findes i Nyaars-Morgen (US IV, 277-278). Se desuden Auken 2005, $391 \mathrm{f}$. 


\section{Vorker af andre forfattere}

Allchin, A. M. (1997), N. F. S. Grundtvig: An Introduction to His Life and Work, Århus.

Auken, Sune (2005), Sagas spejl. Mytologi, historie og kristendom hos N. F. S. Grundtvig, København.

Brodersen, Chr. N. (1952), "I al sin Glans nu straaler Solen", Vendsyssel Tidende, 30. maj 1952.

Cappelørn, Niels Jørgen (2004), “Gudbilledlighed og syndefald: Aspekter af Grundtvigs og Kirkegaards menneskesyn på baggrund af Irenæus”, Grundtvig-Studier 2004, København, 134-178.

Dahn, Helge (1981), Salmehåndbogen, København.

Hansen, Uffe (1937-66), Grundtvigs Salmedigtning, I-III, Odense/København.

Holm, Anders (2001), Historie og efterklang. En studie i N. F. S. Grundtvigs tidskrift Danne-Virke, Odense.

- (2009), To samtidige. Kierkegaards og Grundtvigs kritik af hinanden, København.

Holm, Jette (1999), “Opblomstrer nu Guds Kirkevange”, Vartovbogen, København 1999.

- (2001), Opblomstrer nu Guds Kirkevange el. I al sin Glands nu straaler Solen (Foredrag ved Selskabets årsmøde nov. 2001).

Jensen, Jørgen I. (1995), Den fjerne Kirke, København.

Kjærgaard, Jørgen (2003), Salmehåndbog, København.

Koch, Carl (1925), Grundtvigske Toner, København.

Lundgreen-Nielsen, Flemming (1980), Det handlende ord: N. F. S. Grundtvigs digtning, litteraturkritik og poetik 1798-1819, København.

- (1983), "Grundtvig og romantikken" i Christian Thodberg og Anders Pontoppidan Thyssen (red.), Grundtvig og grundtvigianismen i et nyt lys: Hovedtanker og Udviklingslinier fra de senere Ars Grundtvigforskning, Århus, 19-42.

Møller, Niels (1928), “I al sin Glans nu straaler Solen”, Kirke og Folk, København.

- (1937), "Lidt om Pinsen i dansk salmedigtning", Kirke og Tiden, København.

Nielsen, Erik A. (2009), Kristendommens retorik, København.

- (1988), "Sangværk til den danske kirke", Festskrift til Leif Grane, København.

Paludan-Müller, Fl. (1940) "I al sin glans", Roskilde Stiftsblad, Roskilde.

Stevns, Magnus (1940), "Nogle Naturbilleder fra Grundtvigs Salmer”, Edda, vol XL, 1940, 266-300, optr. i Stevns 1950, 26-57.

- (1950), Fra Grundtvigs salmevarksted, udg. af Henning Høirup og Steen Johansen, København.

Toldberg, Helge (1950), Grundtvigs symbolverden, København.

Tårup, K. (1939), Grundtvigs pinsesalmer, København.

Vaupell, Chr. (1863), Danmarks Skove, København. 
Wigh-Poulsen, Henrik (1996), "Barnet i haven - analyse af et grundtvigsk motiv og dets rødder i en tidlig litterær tradition”, Grundtvig-Studier 1996, København, 58-76.

- (1991), "Sandheds Ånd, Grundtvigs helligåndsteologi og den engelske romantik", Grundtvig-Studier 1991, København.

\section{Bibler}

Bibelen, den Hellige Skrifts kanoniske bøger, København 1992.

Die Bibel, oder die ganze Heilige Schrift alten und neuen Testaments, Martin Luther, 1836 